\title{
Designing Effective Spaces, Tasks and Metrics for Communication in Second Life Within the Context of Programming LEGO NXT Mindstorms ${ }^{\mathrm{TM}}$ Robots
}

\author{
Michael Vallance, Future University Hakodate, Japan \\ Stewart Martin, Teesside University, UK \\ Charles Wiz, Yokohama National University, Japan \\ Paul van Schaik, Teesside University, UK
}

\begin{abstract}
Science education is concerned with the meaningful pursuit of comprehension, knowledge and understanding of scientific concepts and processes. In Vygotskian social constructivist learning, personal interpretation, decision-making and community cooperation fosters long-term understanding and transference of learned concepts. The construction of knowledge requires learners to be actively involved in the process of learning. For effective science learning to take place an instructor's pedagogical approach must be anchored in meaningful contexts so that students have actual opportunities to experience science. This paper presents the early stages of a research project that attempts to assess and define effective measurements for evaluating strategies for communicating science by using LEGO robots and Mindstorms ${ }^{\mathrm{TM}} R C X$ controllers that are collaboratively constructed and programmed by students using virtual technologies while physically situated in different locations.
\end{abstract}

Keywords: $\quad$ Augmented Reality, Communication, Future, LEGO Robot, Science Metrics, Second Life, Virtual Reality, Virtual Worlds

\section{INTRODUCTION}

Science education is concerned with the meaningful pursuit of comprehension, knowledge and

DOI: 10.4018/jvple.2010091703 understanding of scientific concepts and processes. The effective science educator's pedagogical approaches are anchored in meaningful contexts so that students 'experience' science and develop their 'craft' (Thornburg, 2002). Such 'experiential learning' provides learners 
with opportunities to engage with problems that require the retrieval of prior knowledge, offer multiple perspectives of problems and solutions, and facilitate a challenging process which leads to an achievable outcome. Learning does not occur in isolation but involves communication, cooperation and collaboration with fellow learners and experts (Kolb, 1984). In this Vygotskian social constructivist learning perspective, personal interpretation, decision-making and community cooperation fosters long-term understanding and transference of learned concepts. The construction of knowledge requires learners (of science or other subjects) to be actively involved in shaping the learning process.

Researchin the informed use of technology for educational purposes highlights the need to go beyond replication of traditional, didactic practices to an appropriation of digital communication (Warschauer, 1999) facilitated by a constructivist pedagogy (Jonassen \& Land, 2000) to support purposeful tasks (Martin \& Vallance, 2008). The convergence of instructivism, constructionism, social and collaborative learning towards a 'ConversationalFramework' (Laurillard, 2002) provides opportunities for learners to take, "a more active role in learning and for tutors to support learning activities in multimodalways" (deFreitas \& Griffiths, 2008, p. 17). Of course, all of this is not a revelation. Piaget, Dewey and Bruner all advocated the learner being an active participant in the learning process. In a study of the future of work, Thornburg (2002) concluded that today's DigitalAge learners will need to become active learners, effective collaborators who seek and contribute knowledge, and proficient users of online collaboration tools.

One class of collaborative tools gaining traction in Higher Education is virtual worlds. Virtual worlds are persistent computersimulated environments that allow for threedimensional representations of individuals and objects that can be manipulated and modified. Usually, individuals are represented through avatars that have varying degrees of similarity to human appearance. Some virtual worlds such as
Second Life allow for extensive modification of avatars and enable users to build a wide variety of virtual objects. Avatars can walk, fly, sit down, dance, teleport throughout the virtual world and interact with those of other human participants. Users can utilize their avatars to communicate with other avatars using text, voice and gesture. Virtual worlds are increasingly evident in Higher Education courses, and yet the enthusiastic adoption and economic investment in virtual worlds such as Second Life often results in a mirror world; a world that mimics our physical state. For instance, many universities and other educational institutions are establishing a presence in Second Life and have begun to conduct classes and provide other services for students. However, they attempt to replicate the real world through the virtual building of traditional classrooms and activities that do not utilize the uniqueness of the virtual space and its tools. Innovative virtual collaboration requires a uniqueness of contribution by participants (personally or anonymously), synchronously and/or asynchronously (whichever is the most comfortable for the user) with a democratization of the process leading to a sum product greater than the individual contributions (Vallance \& Wiz, 2007). This represents a move from the commonly seen replication of existing practice towards the exploitation of the unique pedagogical affordances offered by emerging technologies-a move from first to second order change (Cuban, 1992).

However, pragmatically and pedagogically, it would be a mistake for practitioners using technology to only consider educational opportunities in virtual spaces. For instance, working with the internet (e.g. broadcast World Wide Web, socialnetworking) and virtual spaces (e.g. interactive Second Life) can represent an amalgamation of real world activities and virtual world activities from which the combined way of working will result in the development of a personal and group artifact that can be imported, modified and exported (e.g. printed out or posted to a Website). Such multiple media artifacts (documents, spreadsheets, slideshows, images, movies) can therefore maintain an in- 
dependent existence in the virtual space thereby allowing for continued modification at any time (synchronously or asynchronously). Moreover, the artifact may not necessarily reside solely in the virtual space but can be additionally downloaded to a computer's hard drive as a virtual collaborative artifact for presentation or archival purposes (Vallance \& Wiz, 2007).

In science education researchers have shown interest in using virtual worlds as they provide a number of benefits: making science relevant to the learner; incorporating current research into the curriculum; providing a means to present opportunities to engage students in authentic scientific inquiry; and giving learners real examples of career possibilities in science (Niemitz et al., 2008). However, de Freitas (2008) in her detailed study of serious virtual worlds for the UK Joint Information Systems Committee (JISC) confirmed the need for, "developing better metrics for evaluating virtual world learning experiences" and also "developing better techniques for creating virtual learning experiences (e.g. frameworks, approaches and models)" (p.11). Perhaps understanding virtual worlds is especially necessary because, "we increasingly live in a world in which opting out of technology systems is more and more difficult and yet participation within those systems pushes us to accept structures we might oppose" (Taylor, 2006, p. 135).

The challenge proffered by de Freitas and others is for educational researchers to develop valid, reliable and transferable metrics for assessing the teaching and learning effectiveness of virtual worlds. The metrics need to relate to student engagement in science-based, collaborative tasks that have quantitatively and qualitatively measured outcomes. In the design and implementation of the constructivist learning experiences, tasks should encourage students to take responsibility for their own learning, including what and how they learn, provide them with opportunities to find solutions and meaning using multiple perspectives, create self awareness of their learning process, make learning relevant and authentic, make learning a collaborative and interactive social experi- ence, and use multiple modes of representation and rich media (Honebein, 1996). In science education, programming a robot to undertake discrete physical movements provides a clear representation of success. LEGO Mindstorms, for instance, enable students to build a robot, input instructions via the NXT Mindstorms software, program the robot to follow the instructions, and subsequently view the physical movements of the programmed robot. In a collaborative environment the robot design and Mindstorms program can then be communicated and taught to another student remotely located. The degree of success of the transfer of process and information can be measured by the physical movements of the 'taught' robot. Reviewing the research on teaching robotics Barker and Ansorge (2007) found that: 1) it is an effective tool for teaching science, engineering, and technology; 2) students who have engineered and programmed robots are exposed to other disciplines that are important for robotics, science and engineering; 3 ) there is exposure to real world conditions with multiple possible solutions; 4) effective teamwork is a significant outcome; and 5) that female students respond positively to working with robots. Combining the teaching of robotics with collaborative technologies and task-based design has potential for increasing university students' science and technological skills. However, this potential can only be realized if clear objectives are established and if educators know how to understand and measure the most effective ways to do this. Researching effective quantitative metrics to evaluate strategies for teaching robotics to university students using collaborative technologies provides a needed foundation for future research and academic staffdevelopment. One outcome of this research is designed to provide a valid, reliable and viable framework for assessing and evaluating outcomes in the fields of science education, robotics, programming, virtual and augmented reality environments, and collaborative technologies. Working in a virtual world can also introduce unforeseen affective factors so using digital capture and facilitating follow up reflection activities by students may 
reveal new information about the process and product of science related tasks conducted in a virtual world.

To summarize, the research project discussed here has been designed to assess and define effective measurements for evaluating strategies for teaching programming using robots (with reflective and touch sensors, independently driven wheels and a LEGO Mindstorms RCX controller) collaboratively constructed and programmed by students using virtual technologies while physically situated in different locations. The research compares different collaborative processes and the effectiveness of each of these in producing specific learning outcomes of remotely located science students who are using collaborative technologies to program robots to follow basic instructions. It is further posited that the research can provide a framework that can be developed for successful implementation of collaborative tasks undertaken in emerging virtual worlds.

\section{METHODOLOGY}

Standardized metrics for measuring the effectiveness of autonomous robots is not universally recognized by those in the field of robotics. An expert in neural networked robotics was interviewed to seek clarification about robot metrics. Our presumption was that engineers working in this field have access to established algorithms and metrics which enable the superiority of one program over other competing designs to be established and that agreed standards exist against which these can be benchmarked. The analogy might be with motor transport, where different engineering solutions can be compared and evaluated for fuel consumption, braking distance, road holding, acceleration or load-carrying. It was explained that this was not the situation in robotics, because each project tended to be built for a specific purpose. Different purposes created different solutions and approaches and because there is no common agreement about the kinds of desirable features of robotic systems in general, unlike with cars or lorries, no common metrics exist to allow engineers to compare different solutions in terms of effectiveness, appropriateness or efficiency. This is not dissimilar to the situation found in the use of technologies to support learning. There are many and sometimes competing desired outcomes for education: in our students we seek subject mastery and recall but also value higher order thinking and reflective and collaborative learning. The means to produce and measure the outputs of one are not necessarily useful for the others. Given this predicament the challenge for educators is to establish the conditions and circumstances that make best use of new technologies.

Our adopted methodology was developed with consideration of Olsen and Goodrich's (2003) quantitative instrument and Martin and Vallance's (2008) qualitative instrument. The participants programmed robots to navigate courses designed by others, and subsequently modified the program to improve navigation on successive attempts. The metrics proposed for assessing the experiment were Task Effectiveness (TE), Interaction Effort (IE), frequency of course navigation, and the time requirement for successful course completion. Communication between groups was carried out using synchronous interactive virtual technologies and all communication was digitally captured, transcribed and analyzed using the approach described in Vallance (2007). The quantitative data set (i.e. Task Effectiveness (TE) - the number of commands successfully programmed into the robot, and Interaction Effort (IE) - the amount of time required to interact with the robot (Olsen \& Goodrich, 2003)) were merged with personalized 'meaning' of data collected via a qualitative data set; i.e. the follow up interviews and digital capture of participants on task. Combining both quantitative and qualitative data sets reduces bias (Brown, 1992). Tasks which employ the virtual world condition need to be considered in terms of whether they will facilitate a meaningful process for producing a challenging but achievable outcome. Prior to implementing the tasks, communication and robot programming, a virtual learning space 
was designed using a futures studies method. The futures studies method supports the development of possible, probable and preferable futures through the use of scenarios. This involves an analysis, a critique and a panoramic view of present designs in order to facilitate a discussion and an ownership of the change process (Groff \& Smoker, 1997).

Finally, it is recognized that as an intervention this research may be "fleeting and fragile, not readily transportable to settings outside the innovator's control" (Brown, 1992, p. 171). However, the research is designed to observe the iterative process of successful, science related tasks for learning in a virtual world which will in turn support the development of transferable metrics and a framework for meaningful education with tangible, quantifiably measured outcomes.

\section{IMPLEMENTATION}

This section summarizes six tasks conducted in a virtual world by students in Japan whilst physically distant at the time of implementation. The tasks discussed in this paperwere iteratively developed in two phases. Phase 1 consisted of two tasks with the aim of designing and building a learning space within Second Life. Phase 2 consisted of four tasks with the aim of communicating a LEGONXT Mindstorms program within the learning space. The two participants involved in this research project had no prior experience of virtual worlds or LEGO NXT Mindstorms programming. The remit for Taro (the name of student 1; avatar name - Hotaru Kurmin) was to design a learning space within leased land in Second Life. The remit for Toshi (student 2; avatar name - Soka Naidoo) was to teach LEGO NXT Mindstorms programming by communicating in the designed Second Life learning space. Phase 3 of the research, not discussed in this paper, will consist of further tasks of increasing navigational complexity for robot transit and Mindstorms programming conducted by students from Japan and the UK.
To begin the design process, a class of design students taught by one of the researchers were asked to digitally create a classroom of the future that could then be built within a virtual world. To implement this process a 'futures studies' method (Groff \& Smoker, 1997) was employed. In education contexts, futures studies is systematic learning to create, process and communicate new insights. Cognitive theories of learning can be broadly categorized using a dichotomy of convergent and divergent thinking. Convergent thinking involves bringing material from a variety of sources to produce solutions using description, observation, prioritization and deduction (a process is most easily recognized in fields such as mathematics and science). Divergent thinking is exemplified by the creative elaboration of ideas prompted by a stimulus (Iversen, n.d). Educational contexts often feature learning within the continuum from convergent to divergent thinking. In recognition of this continuum, futures studies employs a number of techniques such as triangulation (push-pull-weight) and scenarios in order to succinctly contextualize, illustrate and communicate new designs. Iversen posits that the use of scenarios allows for a mix of convergent and divergent thinking thereby facilitating the rich interpretations of scenarios as they develop. Although beyond the scope of this paper it is important to indicate the use of these systematic processes that were involved in all stages of this research project. Towards the end of the design course all futures scenarios were presented to Taro (student 1) who then selected a 'classroom of the future' design to build in Second Life.

Meanwhile, Toshi (student 2) constructed and duplicated a LEGO robot. One was given to Taro who had to program the robot to follow a pre-determined circuit as instructed by Toshi through synchronous communication in Second Life. The LEGO related tasks further enabled Taro to modify the design of the learning space resulting in the desired tools (i.e. media viewer, presenter, and options wall) to support text and voice communication, plus moveable and copi- 


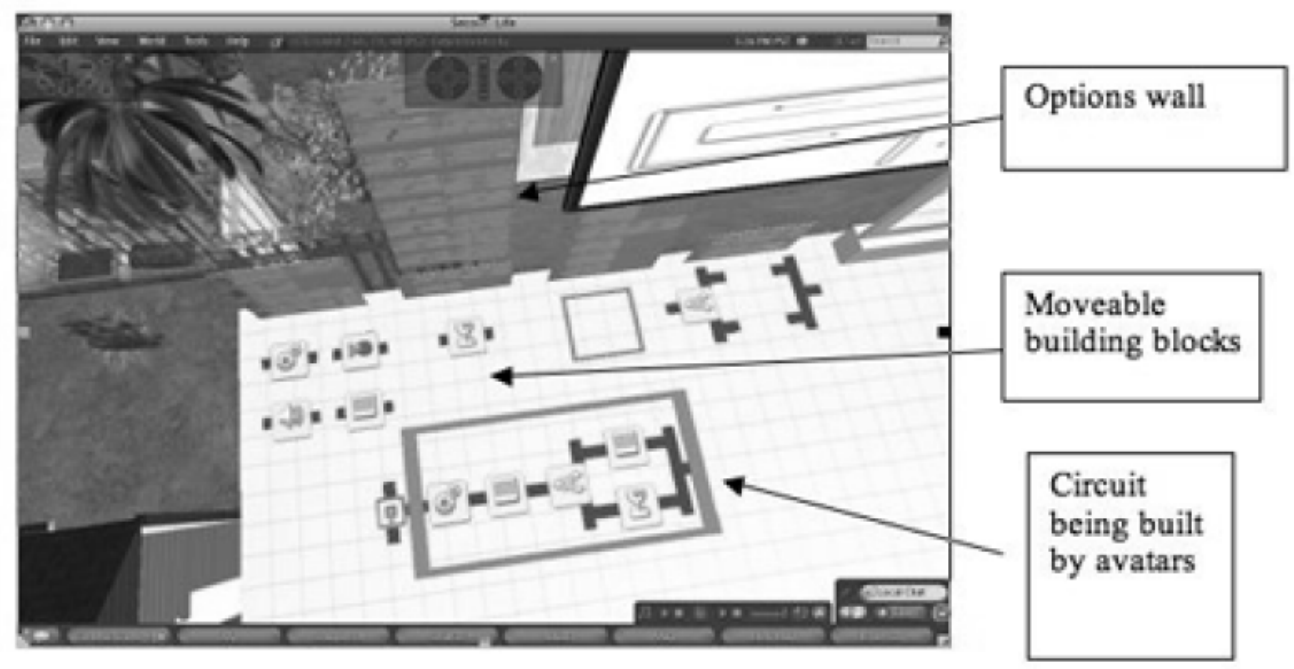

able NXT program blocks within the Second Life learning space (see Figures 1 to 3 ).

The designed Second Life learning space consisted of two levels with transparent walls. The lower level space was used as a sandbox (the term used in Second Life for avatars to learn how to construct and modify objects). A media viewer or presenter with images previously uploaded was also available for avatars to use. The media presenter is essentially a presentation screen connected to a virtual laptop. Pressing the keyboard on the laptop changes the image on the presenter. Avatars can upload images from their own inventory. The second level provided tools for the LEGO experiments. Again, a media presenter was available. Next to the media presenter was a video streaming screen. This enabled live video to be streamed from a student's physical working area (via a video camera connected to a networked computer). The screen also displayed fixed images in a similar way to the aforementioned presenter. On the sides (named Options walls by the students) of the second level were images of the NXT configuration panels (see Figure 1). These were displayed so that students could point and focus on specific configurations that needed to be inputted in order to replicate the operation of the assembled robots. On the floor were the customizable objects representing the NXT software programming blocks. During the implementation the avatars would meet on the second level and together reconstruct their NXT program. Figure 3 illustrates a NXT program circuit being constructed. The avatars used both voice and text to communicate, made reference to the Options wall by pointing and zooming in to specific configuration panels, constructed new NXT objects (using the 'Shift and drag' computer operation), and moved the NXT objects (see Figures 2 and 3) to construct the program required to upload to the LEGO robot (see Figure 4).

Once the learning space had been built, six tasks were implemented. Each task required avatars to communicate and collaborate to create a successful outcome. The initial intention was for students to become active and engaged in the experience of working and learning within the virtual world. The initial tasks aimed to familiarize students with the communication and navigation tools within Second Life (see Table 1). 
Figure 2. Avatars collaborating in Second Life

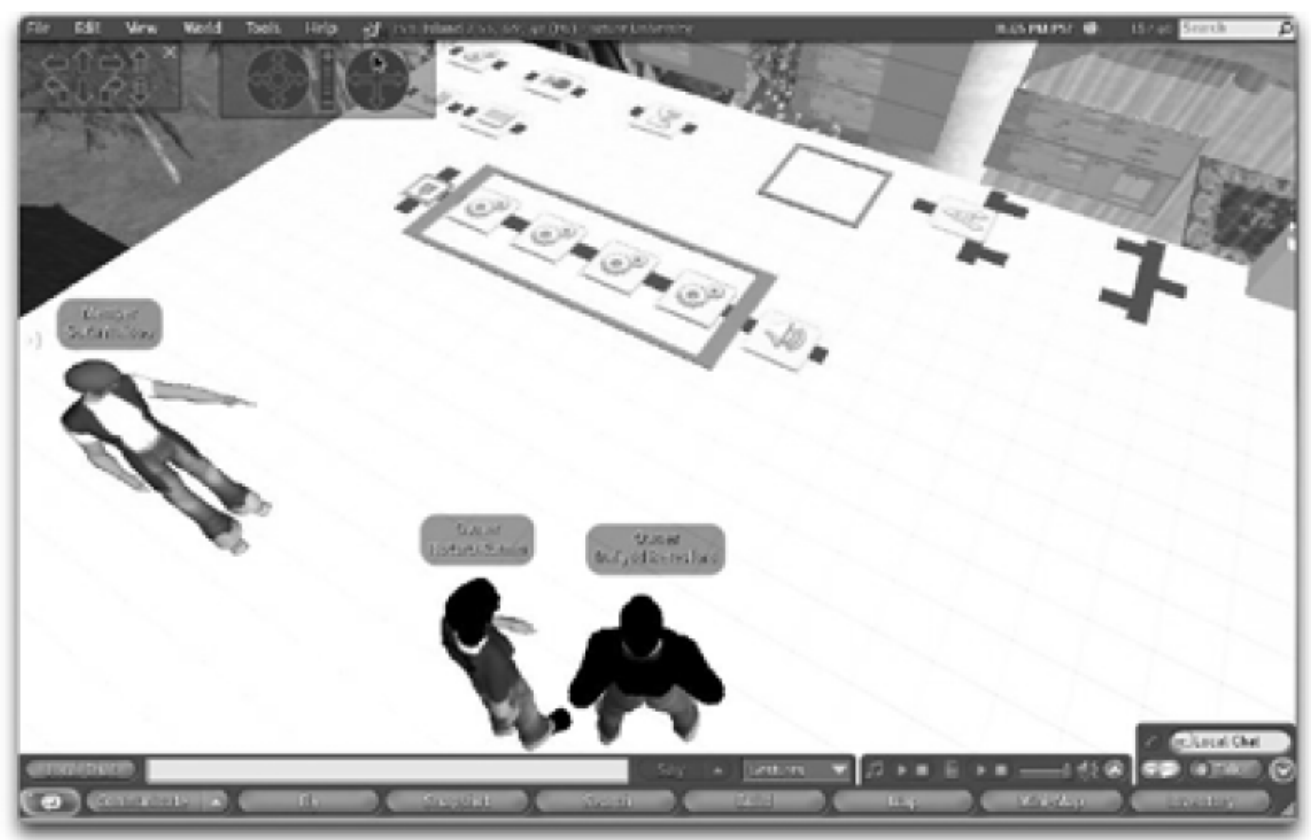

Figure 3. Manipulating LEGO NXT Mindstorms blocks in Second Life

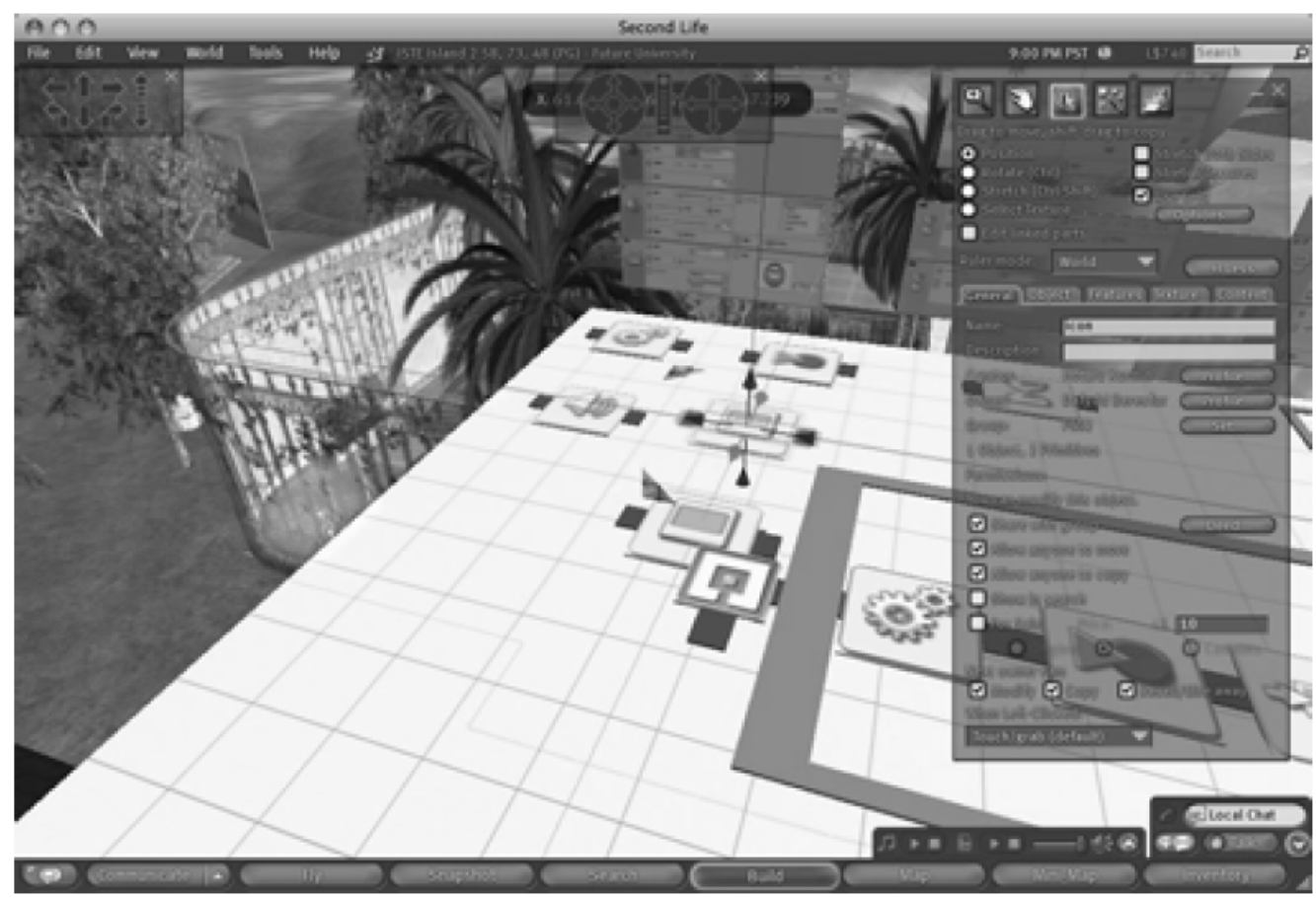

Copyright (C) 2010, IGI Global. Copying or distributing in print or electronic forms without written permission of IGI Global is prohibited. 
Figure 4. LEGO NXT Mindstorms interface

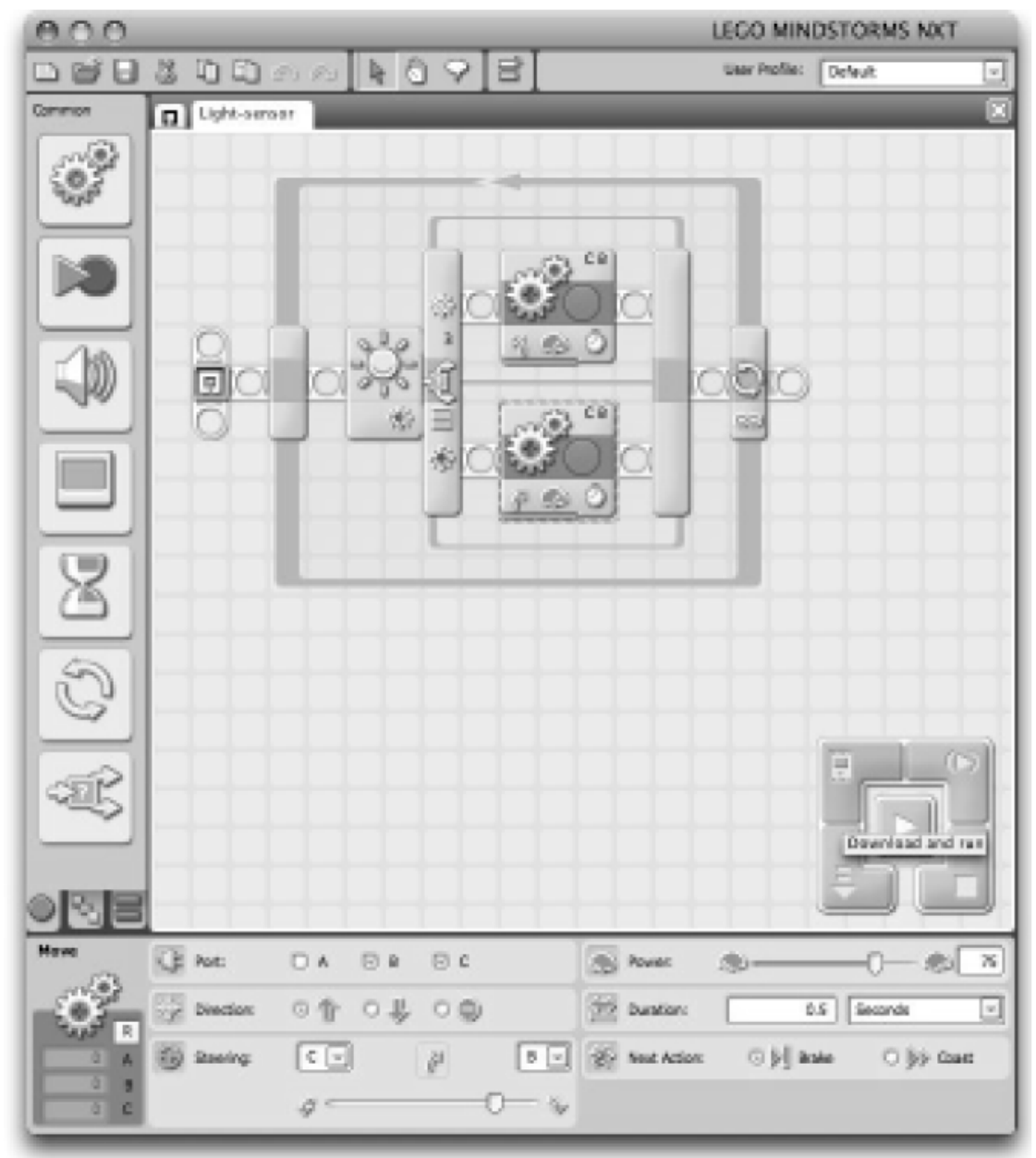

In tasks 3 to 6 the use of NXT program blocks as manipulative, interactive images was included on the horizontal floor of the learning space while NXT block variables were represented as vertical images. Students were remotely located and used avatars in Second Life for communication. The activities were conducted using voice and text. Student A (avatar: Soka Naidoo) re-arranged the NXT blocks in Second Life (see Figure 2) to replicate the Mindstorms program (see Figure 4). Student B (avatar: Hotaru Kurmin) simultaneously programmed NXT as instructed. He later uploaded the resultant program to the LEGO robot via a physical USB cable and tested the robot on a classroom floor. The students also printed the interface images so that they could record their information. The students reported that they felt more comfortable when blending familiar analog tools with the new digital collaboration. All the images of the Mindstorms interface and target circuit were uploaded and viewable on a screen within the Second Life learning space (see Figure 1). Both students could switch images on the viewable screen at any time, if desired. The communication was thus augmented by the synchronous display of the images in the virtual space. The synchro- 
Table 1. Initial task reflections by participants

\begin{tabular}{|c|c|c|c|}
\hline $\begin{array}{c}\text { Task } \\
\text { number }\end{array}$ & Task & Reflection (+/-) & $\begin{array}{l}\text { Implementation for } \\
\text { subsequent task }\end{array}$ \\
\hline 1 & $\begin{array}{l}\text { The students were provided } \\
\text { with two pictures of a town } \\
\text { centre. However, picture B con- } \\
\text { tained missing information. The } \\
\text { purpose was to find the location } \\
\text { of a number of buildings such } \\
\text { as the law courts, hospital, post } \\
\text { office, etc. The students were } \\
\text { then provided with print outs } \\
\text { of two spreadsheets containing } \\
\text { prices of hardware components. } \\
\text { The purpose was to share infor- } \\
\text { mation and determine the most } \\
\text { economical shop at which to } \\
\text { purchase particular components }\end{array}$ & $\begin{array}{l}\text { What was difficult? } \\
\text { Confirming the task was difficult } \\
\text { because of English. } \\
\text { Only text chat used. } \\
\text { Did not look at each avatar so did } \\
\text { not know other's actions. } \\
\text { I did not check the text while } \\
\text { chatting. } \\
\text { We did not know that we had dif- } \\
\text { ferent information. I did not check } \\
\text { or confirm the task. } \\
\text { What was easy? } \\
\text { Using SL is enjoyable, visual, } \\
\text { comfortable. } \\
\text { Moderator's comment. } \\
\text { Two activities in } 30 \text { minutes } \\
\text { were too intense. Although basic } \\
\text { gap filling activities, they were } \\
\text { quite tough for the students. The } \\
\text { second activity flowed smoothly } \\
\text { and would be a good introductory } \\
\text { activity for those students being } \\
\text { familiarized with, and communi- } \\
\text { cating in, SL. }\end{array}$ & $\begin{array}{l}\text { What would you like to } \\
\text { do next time? } \\
\text { Use Japanese. } \\
\text { Use pictures. }\end{array}$ \\
\hline 2 & $\begin{array}{l}\text { Two images of a town were up- } \\
\text { loaded to the SL space presenter } \\
\text { and viewable on the big screen. } \\
\text { The students had to determine } \\
10 \text { differences between the } 2 \\
\text { images. }\end{array}$ & $\begin{array}{l}\text { What was difficult? } \\
\text { We did not look at the two pictures } \\
\text { simultaneously. } \\
\text { One avatar did not teleport im- } \\
\text { mediately so we did not know what } \\
\text { was happening (technical problem } \\
\text { in SL). } \\
\text { Took a long time. } \\
\text { English text. } \\
\text { What was easy? } \\
\text { We used picture screen. } \\
\text { Text chat was easier. } \\
\text { Lots of checking in text chat. } \\
\text { All sentences were short. } \\
\text { Moderator's comment. } \\
\text { Students were remotely located } \\
\text { so used avatars for communica- } \\
\text { tion. They had to use text only. } \\
\text { Language was English only. The } \\
\text { two images were viewable on } \\
\text { the SL presenter. Both students } \\
\text { could switch images at any time, } \\
\text { if desired. }\end{array}$ & $\begin{array}{l}\text { What would you like to } \\
\text { do next time? } \\
\text { Japanese. } \\
\text { Want two projector/image } \\
\text { screens on same level (not } \\
\text { two levels and fly). } \\
\text { Prior check of SL connec- } \\
\text { tion and bandwidth. }\end{array}$ \\
\hline
\end{tabular}

nous, multi-modal communication provides an advantage over asynchronous forms of digital communication. For instance, in tasks 5 and 6 the NXT building blocks were moved around forming the program that had to be replicated in the actual NXT software. This presented a 
visual image that could be altered in real time through negotiation between the two avatars. Finally, Soka Naidoo's and Hotaru Kurmin's robots were then operated and evaluated for comparison. For ease of checking the Task Effectiveness (TE) and Interaction Effort (IE), the students were located together in real life. Moreover, all actions, text and voice data were digitally captured. The voice data was transcribed and analyzed using language function codes in TAMS analyzer (see Results section). Table 2 highlights the reflections made by the students in follow up interviews.

To summarize, in the development of tasks and metrics for communication in newly conceptualized and designed virtual spaces, we have identified a number of characteristics which contributed to the students' successes in completing synchronous tasks involving the programming of LEGO robots:

- The use of voice for interaction, use of text for confirmation;

- Use of arrow and zoom function in Second Life to focus upon details within images;

- Use of two presenters for displaying images;

- Use of customizable and moveable blocks;

- The need for structured exchanges, and promotion of confirmatory exchanges;

- Blend familiarity such as use of printbased materials.

\section{RESULTS AND DISCUSSION}

The remaining section of this paper will interpret the process of designing effective spaces, tasks and metrics for communication in Second Life within the context of programming LEGO robots using NXT Mindstorms software. First, an explanation of the tasks' processes and observations will be offered. Then an analysis of the communication involved in the tasks' discourse will be summarized. This analysis will then be coupled with an informed, initial proposal for effective metrics when conducting educational tasks in virtual worlds such as Second Life.

The design of the virtual space in Second Life followed a prescribed form that, we argue, provides credibility and functionality over commercial designs that often emphasize aesthetics. This was important as it provided ownership of the space to the participants. The next step involved the implementation of tasks developed iteratively (six in total at this stage of the research). The aim of each task was to communicate the programming of a LEGO robot. The quantitative measure of amount of success was Task Effectiveness (TE) - the number of commands successfully programmed into the robot, and Interaction Effort (IE) - the amount of time required to interact with the robot. Upon reflection, the tasks at this stage of the research were quite straightforward; possibly less challenging than anticipated but certainly with achievable outcomes. Given the innovative application of such educational practices, this cautious approach resulted in rich qualitative data. All multiple media actions and communication (text and voice) were digitally captured and after transcribing the communications, the text was tagged for communicative functions using TAMS Analyzer. The functions were: independently providing information (22\%); asking questions (21\%); confirming information previously provided (18\%); answering a question with an affirmative statement (15\%); expressing an observation (8\%); making a suggestion (4\%); giving a direct instruction $(3 \%)$; praising $(3 \%)$; making a request $(2 \%)$; answering a question with a negative statement (1\%); apologizing (1\%); greeting (1\%).

The complexity of the linguistic code was quite low although the interpretive density (i.e. the complexity of the operations which need to be carried out (Candlin, 1987) may be considered high, as illustrated in Table 3.

As the students progressed through the tasks there was a familiarity and continuity of the process as the learners related more to the task. Such cognitive familiarity reduces 
Table 2. Task reflections

\begin{tabular}{|c|c|c|c|}
\hline & Task & Reflection (+/-) & $\begin{array}{c}\text { Implementation } \\
\text { for subsequent } \\
\text { task }\end{array}$ \\
\hline 3 & $\begin{array}{l}\text { Two images of the LEGO } \\
\text { NXT Mindstorms software } \\
\text { were uploaded to the SL } \\
\text { space presenter. Student A } \\
\text { had to teach student B. }\end{array}$ & $\begin{array}{l}\text { What was difficult? } \\
\text { Used text took a long time. } \\
\text { Some information was misunderstood because the ex- } \\
\text { pert explained the incorrect use of interface (it should } \\
\text { have been What is it called? but was taught as What } \\
\text { does it do?). } \\
\text { Did not know what the student was doing. } \\
\text { What was easy? } \\
\text { Japanese. } \\
\text { We understood difficult contents because used Japa- } \\
\text { nese text. } \\
\text { Felt natural. } \\
\text { Printout plus SL use for activity. } \\
\text { One avatar was the expert. So felt easy. } \\
\text { Student looked at the pictures in the presenter. } \\
\text { Moderator's comment. } \\
\text { Students covered most of my observations. I wish they } \\
\text { used the presenter more effectively though. In this task } \\
\text { it became evident that having an avatar as an expert } \\
\text { 'felt easy' (see students' comment above) despite the } \\
\text { unusual (for Japanese students) roles adopted (i.e. } \\
\text { one expert, one non-expert). Jumping into these roles } \\
\text { without prior formalities of status acknowledgment is } \\
\text { culturally difficult for the Japanese students. This was } \\
\text { confirmed in a much later follow up interview when } \\
\text { one student remarked that when talking to a teacher he } \\
\text { would feel tense and this was felt also in Second Life. }\end{array}$ & $\begin{array}{l}\text { What would you } \\
\text { like to do next } \\
\text { time? } \\
\text { Expert student } \\
\text { must confirm or } \\
\text { check understand- } \\
\text { ing. } \\
\text { Use voice. }\end{array}$ \\
\hline 4 & $\begin{array}{l}\text { Two new images of the } \\
\text { LEGO NXT Mindstorms } \\
\text { software were uploaded } \\
\text { to the SL space presenter. } \\
\text { Student A had to teach } \\
\text { student B. }\end{array}$ & $\begin{array}{l}\text { What was difficult? } \\
\text { Voice level up and down so difficult to listen. } \\
\text { Voice was fast but had to write on printout when } \\
\text { expert was talking. } \\
\text { Technical issue - surrounding noise heard by other } \\
\text { avatars. Recommend using headphones and micro- } \\
\text { phones. } \\
\text { No voice chat log so cannot see previous communica- } \\
\text { tion (but can in text chat). } \\
\text { What was easy? } \\
\text { Voice is better than text. } \\
\text { Easy to ask questions. } \\
\text { Very quick - } 10 \text { to } 15 \text { mins. } \\
\text { Efficient use of time unlike text which takes too long. } \\
\text { Moderator's comment. } \\
\text { I felt they did not use the function of the presenter } \\
\text { (i.e. switching images) which would have been useful. } \\
\text { Students used text communication to structure difficult } \\
\text { interactions (e.g. they used text for confirming and } \\
\text { providing NXT configuration details) but preferred } \\
\text { voice communication for most interactions as it was } \\
\text { faster and felt natural. }\end{array}$ & $\begin{array}{l}\text { What would you } \\
\text { like to do next } \\
\text { time? } \\
\text { Student must ask } \\
\text { to wait. } \\
\text { Expert must check } \\
\text { understanding by } \\
\text { using text chat - } \\
\text { not voice. }\end{array}$ \\
\hline
\end{tabular}




\section{Table 2. continued}

\begin{tabular}{|c|c|c|c|}
\hline & Task & Reflection (+/-) & $\begin{array}{c}\text { Implementation } \\
\text { for subsequent } \\
\text { task }\end{array}$ \\
\hline 5 & $\begin{array}{l}\text { Images of the LEGO NXT } \\
\text { Mindstorms software were } \\
\text { previously uploaded to the } \\
\text { SL space presenter and Op- } \\
\text { tions wall. Student A had to } \\
\text { teach student B to program } \\
\text { the robot to follow specific } \\
\text { instructions. No specific } \\
\text { circuit was required so no } \\
\text { circuit image uploaded. } \\
\text { This open-ended task may } \\
\text { be construed as increasing } \\
\text { the cognitive load required } \\
\text { to conduct the task. How- } \\
\text { ever, it was felt that student } \\
\text { B needed to become more } \\
\text { familiar with the NXT } \\
\text { objects. }\end{array}$ & $\begin{array}{l}\text { What was difficult? } \\
\text { Voice was unclear today so had to revert to text. } \\
\text { What was easy? } \\
\text { Japanese usage. } \\
\text { Previous familiarity with NXT interface (Activities } 3 \\
\text { and 4) essential. } \\
\text { Moderator's comment. } \\
\text { The activity lasted } 20 \text { minutes and went smoothly. } \\
\text { The communication process this time was much more } \\
\text { effective (se Table } 3 \text { for an analysis). The two robots } \\
\text { were identically programmed successfully. } \\
\text { The implementation of the innovation to create three } \\
\text { dimensional representations of the NXT objects (as } \\
\text { opposed to the two dimensional view of the NXT } \\
\text { software) in SL was undertaken. The 3D representation } \\
\text { of NXT software objects allowed the users to physi- } \\
\text { cally move the objects around and create the program } \\
\text { which was then replicated quickly into the actual NXT } \\
\text { software. }\end{array}$ & $\begin{array}{l}\text { What would you } \\
\text { like to do next } \\
\text { time? } \\
\text { Create NXT soft- } \\
\text { ware objects as 3D } \\
\text { objects in SL. }\end{array}$ \\
\hline 6 & $\begin{array}{l}\text { Student A (avatar: Soka } \\
\text { Naidoo) to teach student } \\
\text { B (avatar: Hotaru Kurmin) } \\
\text { how to program the LEGO } \\
\text { NXT Mindstorms software } \\
\text { so that the robot would } \\
\text { traverse a particular circuit: } \\
\text { forward/stop/turn } 90 \text { de- } \\
\text { grees left/forward/ stop/turn } \\
90 \text { degrees left/forward/ } \\
\text { stop/turn } 90 \text { degrees left/ } \\
\text { forward/ stop. Return to } \\
\text { original position. }\end{array}$ & $\begin{array}{l}\text { What was difficult? } \\
\text { Nothing in particular today. Maybe the final USB con- } \\
\text { nection to the physical robot as it failed first time but } \\
\text { tried again and succeeded. } \\
\text { What was easy? } \\
\text { Japanese usage. } \\
\text { Previous familiarity with NXT interface. } \\
\text { The building blocks helped very much. } \\
\text { Moderator's comment. } \\
\text { The activity lasted } 20 \text { minutes and was successfully } \\
\text { completed. NXT building blocks were moved around } \\
\text { forming the program that had to be replicated in the } \\
\text { actual NXT software. Program 'building blocks' were } \\
\text { manipulated. On the walls were the various options for } \\
\text { each block. The blocks were moved by both avatars. } \\
\text { The options were communicated by voice and text. A } \\
\text { thick blue arrow allowed avatars to point for physical } \\
\text { direction and focus. A picture of the robot was also } \\
\text { uploaded so that ports could be identified (this was for } \\
\text { the USB connector). }\end{array}$ & $\begin{array}{l}\text { What would you } \\
\text { like to do next } \\
\text { time? } \\
\text { Teacher (Soka } \\
\text { Naidoo) did most } \\
\text { of the actual build- } \\
\text { ing. Need to allow } \\
\text { student (Hotaru) } \\
\text { to move building } \\
\text { blocks too. } \\
\text { Add more pictures } \\
\text { to image presenter } \\
\text { during the pro- } \\
\text { gramming process. } \\
\text { This will be more } \\
\text { applicable as the } \\
\text { program becomes } \\
\text { more sophisticated. }\end{array}$ \\
\hline
\end{tabular}

communicative stress and increases cognitive processing (Skehan, 1998) evidenced by better organization of the information being communicated, a clarity of information through question and confirmation discourse, a greater amount of information being communicated in later tasks, and the type of information being more specific, concrete and contextualized to the task objectives (see Table 4).
There is also evidence of a change of the Japanese students' construction process in considering how they are learning in the virtual world. This is revealed in a post-task reflection interview with the participants:

\section{Toshi could know through his Graduate Study that before starting this project he just learned by doing assigned work and not seriously think}


Table 3. Interpretive density

\begin{tabular}{|c|c|c|}
\hline Task & Communication & $\begin{array}{l}\text { Operation } \\
\text { being } \\
\text { undertaken }\end{array}$ \\
\hline 3 & $\begin{array}{l}\text { [19:07] SoKa Naidoo: 8番は、「スイッチ」を意味します。No. } 8 \text { means “switch". } \\
\text { [19:07] SoKa Naidoo: 分岐の動作を行えます。It enables you to activate branching } \\
\text { behavior. } \\
\text { [19:08] Hotaru Kurmin: 例えばどのような分岐があるのですか? Could you give me } \\
\text { examples of the types of branching? } \\
\text { [19:08] SoKa Naidoo: 光センサーを用いて、明るさで条件を付けて分岐出来ます。By } \\
\text { using the light sensor, setting conditions on brightness, you can branch. } \\
\text { [19:09] SoKa Naidoo: 他にも色んなセンサーでも行えます。In addition to that, } \\
\text { branching can be done by various sensors, too. } \\
\text { [19:10] Hotaru Kurmin: 光センサーは暗さ明るさの加減で分岐するのですか?Does } \\
\text { the light sensor branch depending on light intensity? } \\
\text { [19:10] SoKa Naidoo: そうです。具体的な数值を入力して条件を付けます。That's } \\
\text { right. You need to attach conditions to it by entering concrete numbers. } \\
\text { [19:11] Hotaru Kurmin: わかりました。I understand. }\end{array}$ & $\begin{array}{l}\text { At this stage of } \\
\text { task } 3 \text { avatar } \\
\text { Soka Naidoo is } \\
\text { explaining the } \\
\text { basic functions } \\
\text { of the light } \\
\text { sensor in the } \\
\text { NXT program. }\end{array}$ \\
\hline 4 & $\begin{array}{l}\text { [00:02:15] SoKa Naidoo: 2番いってよろしいですか。Can I start talking about No.2 } \\
\text { now? } \\
\text { Hotaru Kurmin: はい、お願いします。Yes, please. } \\
\text { SoKa Naidoo: はい、次に2番は、場合分けでセンサーを OK. The No.2 button } \\
\text { [00:02:30] SoKa Naidoo: 選んだので、制御に使うセンサーを、決めるボタンで } \\
\text { す。[cont'] } \\
\text { decides which sensor needs to be used for control, since the sensor is selected based on } \\
\text { the situation. } \\
\text { Hotaru Kurmin: 場合分けで、セン、セン、センサーを選、選んだので Did you just say } \\
\text { “since the sensor is selected based on the situation"? } \\
\text { [00:02:45] SoKa Naidoo: はい。Yes, I did. } \\
\text { Hotaru Kurmin: んと、その制御を決める Um, I am not so clear on the function of the } \\
\text { button to decide the control. } \\
\text { SoKa Naidoo: はい、つまり、あの、制御を、制御に使うセンサーを決めるボタンです。 } \\
\text { Yes, I mean, you use this button which is applied to fix the sensors to control the } \\
\text { controls. } \\
\text { Hotaru Kurmin: あ、なるほど。I see. } \\
\text { [00:03:00]Hotaru Kurmin: 例えば、あの、光センサーだとかタッチセンサーみたいな } \\
\text { ことで } \\
\text { すね。 For instance, it is similar to optical sensors or touch sensors, isn't it? } \\
\text { SoKa Naidoo: はい、そうです。 That's right. } \\
\text { SoKa Naidoo: え、次よろしいですか。Shall we move on to the next? } \\
\text { Hotaru Kurmin: わかりました。Of course. }\end{array}$ & $\begin{array}{l}\text { At this stage of } \\
\text { task } 4 \text { avatar } \\
\text { Hotaru Kurmin } \\
\text { is checking his } \\
\text { understanding } \\
\text { of the func- } \\
\text { tions of the } \\
\text { light sensor as } \\
\text { he knows he } \\
\text { will need this } \\
\text { information for } \\
\text { programming } \\
\text { the robot later. }\end{array}$ \\
\hline
\end{tabular}

about the way of learning. But he found he had to do everything by himself and think about a 'way' of learning at each step. He had not been aware of this kind of learning before. So there are many ways to learn. He realized the traditional way of learning is just one way of learning. Note that this is a translated report of Toshi's Japanese comments.
There is further evidence of change as students reflected on their prior experiences as 'learning by body' whereas being involved in the research introduced these students to the concept of 'learning by theory'.

Participating in the Second Life research the students commented that experiential learning was difficult and required more time than anticipated. The students had also never experienced 
Table 3. continued

\begin{tabular}{|c|c|c|}
\hline Task & Communication & $\begin{array}{l}\text { Operation } \\
\text { being } \\
\text { undertaken }\end{array}$ \\
\hline 5 & $\begin{array}{l}\text { [21:09] SoKa Naidoo: 緑の歯車のアイコンをドラッグしてください。Could you drag the } \\
\text { green gear wheel shaped icon? } \\
\text { [21:10] Hotaru Kurmin: } \\
\text { [21:10] Dafydd Beresford: i am observing } \\
\text { [21:10] SoKa Naidoo: 持続時間を4回転にします。You have to make the "persistence } \\
\text { time" [last] for } 4 \text { revolutions. } \\
\text { [21:11] Hotaru Kurmin: しました I did. } \\
\text { [21:11] Hotaru Kurmin: 単位はなにでしょうか? What is the unit? } \\
\text { [21:12] SoKa Naidoo: 文字は全て英語になってますか Are all the characters written } \\
\text { in English? } \\
\text { [21:12] Hotaru Kurmin: 現在はrotationsになっています Currently, it is the "rotations". } \\
\text { [21:12] Hotaru Kurmin: はい Over to you. } \\
\text { [21:13] Hotaru Kurmin: degreesです It is the “degrees". } \\
\text { [21:15] Hotaru Kurmin: 一番最初のrotationsですね It is the first "rotations", isn't it? } \\
\text { [21:15] SoKa Naidoo: はい。Yes, that's right. } \\
\text { [21:15] SoKa Naidoo: 次に Next... }\end{array}$ & $\begin{array}{l}\text { At this stage of } \\
\text { task } 5 \text { avatar } \\
\text { Hotaru Kurmin } \\
\text { is fine tuning } \\
\text { one of the pro- } \\
\text { gram blocks. } \\
\text { He is following } \\
\text { avatar Soka } \\
\text { Naidoo's direc- } \\
\text { tions being } \\
\text { displayed in } \\
\text { the Second } \\
\text { Life learning } \\
\text { space. }\end{array}$ \\
\hline 6 & $\begin{array}{l}\text { Soka Naidoo:で、次に.Next... } \\
\text { [00:01:45] Soka Naidoo:左に曲がります。You have to turn left. } \\
\text { Hotaru Kurmin:はい。OK. } \\
\text { Soka Naidoo:で、それはこの半分くらいです。And, it is half the size as the last time. } \\
\text { Hotaru Kurmin:はい、は、半分と言いますと?What do you mean by half the size? } \\
\text { Soka Naidoo:その、1.5センチくらいでいいです...I mean the distance to proceed..... } \\
\text { [00:02:00] Soka Naidoo:その進む距離は。[cont'] is about } 1.5 \mathrm{~cm} . \\
\text { Hotaru Kurmin:はい、わかりました。 I see. } \\
\text { Soka Naidoo:で、次にまた左に曲がります。Then, you need to turn left again. } \\
\text { Hotaru Kurmin:はい。 OK. } \\
\text { Soka Naidoo:で、次はさっき最初に書いたのと同じ長さです。3センチくらいです。This } \\
\text { time, the length is as same as the first time. It's about } 3 \text { cm. } \\
\text { [00:02:15] Hotaru Kurmin:はい。OK. } \\
\text { Soka Naidoo:で、ここから左に曲がります。Now, can you turn left from this point? } \\
\text { Hotaru Kurmin:はい。OK. } \\
\text { Soka Naidoo:で、最初の位置に戻った感じですか?Have you reverted to the position } \\
\text { where you had started? } \\
\text { [00:02:30] Hotaru Kurmin:あ、はい。最初の位置に戻るように矢印を書けばいいん } \\
\text { ですね?Yes, I have. I just need to draw an arrow so that it comes back to the starting } \\
\text { point, right? } \\
\text { Soka Naidoo:はい。That's correct. } \\
\text { Hotaru Kurmin:はい、書きました。I finished drawing it. } \\
\text { Soka Naidoo:で、最後にその位置でまた左に曲がります。 Good. Finally, you've got } \\
\text { to turn left one more time. } \\
\text { Hotaru Kurmin:あ、はい、わかりました。OK, no problem. }\end{array}$ & $\begin{array}{l}\text { At this stage of } \\
\text { task } 6 \text { avatar } \\
\text { Hotaru Kurmin } \\
\text { is adjusting one } \\
\text { of the program } \\
\text { blocks in Sec- } \\
\text { ond Life and } \\
\text { also adding the } \\
\text { co-ordinates } \\
\text { as explained } \\
\text { by avatar Soka } \\
\text { Naidoo. Both } \\
\text { a vatars are } \\
\text { questioning } \\
\text { and confirming } \\
\text { completion of } \\
\text { each step. }\end{array}$ \\
\hline
\end{tabular}

this approach to learning where they were expected to reflect upon each of their actions. Kendo fencing was used as a Japanese analogy. In practicing kendo, students 'do' many times (repetition and practice) and this would be considered 'learning by body'. In addition, prior to the samurai age, Japanese scholars learned classical Chinese theory of ethics or politics 'by memory'. Therefore, traditionally in Japan, learning has been 'learning by body' and 'learning by memory'. Learning by theory is considered relatively new to Japanese society. However, the students stated that they were positive about this 'new way of learning' and that it became easier to learn throughout the duration of the research. Note that this is 
Table 4. Example of familiarity of programming process in latter stages of Task 6

\begin{tabular}{|c|c|}
\hline Communication & $\begin{array}{c}\text { Operation being } \\
\text { undertaken }\end{array}$ \\
\hline $\begin{array}{l}\text { [00:06:30] Soka Naidoo:次の2個目のブロックに移動してください。Can you move to the } \\
\text { second block? } \\
\text { Hotaru Kurmin:はい。OK. } \\
\text { Soka Naidoo:で、ステアリングってありますか?And, do you see a steering wheel there? } \\
\text { Hotaru Kurmin:ステアリング、はい。A steering wheel..... Yes, I do. } \\
\text { [00:06:45] Soka Naidoo:ステアリングをCですね、左いっぱいにしてください。左端で } \\
\text { す。Can you set the steering wheel to C until it doesn't turn left anymore? It is on the } \\
\text { extreme left. } \\
\text { Hotaru Kurmin:はい、左いっぱいにしました。Yes, I had it turn left until it can't be } \\
\text { moved anymore. } \\
\text { Soka Naidoo:はい。で、持続時間の単位を...Good. Then, can you make the unit of the } \\
\text { "persistence time”... } \\
\text { Hotaru Kurmin:はい。Uh huh. } \\
\text { [00:07:00] Soka Naidoo:度、度にしてください。[cont'] degree? } \\
\text { Hotaru Kurmin:度、はい。度にしました。The degree... All right, I have set the unit to } \\
\text { degree. } \\
\text { Soka Naidoo:で、数值は180です。Currently, the number needs to be set to } 180 \text {. } \\
\text { Hotaru Kurmin:はい。あ、180にしました。Right. I have just set it to } 180 . \\
\text { [00:07:15] Soka Naidoo:はい。で、次、3つ目いいですか? Excellent. Now, may I } \\
\text { move on to the third one? }\end{array}$ & $\begin{array}{l}\text { At this stage of task } 6 \\
\text { the turning coordinates } \\
\text { are being finely tuned } \\
\text { in the NXT program } \\
\text { within Second Life. } \\
\text { The communication has } \\
\text { become more specific } \\
\text { to the details required } \\
\text { by both avatars and } \\
\text { subsequently displays } \\
\text { an understanding of the } \\
\text { communicativeandpro- } \\
\text { gramming processes. }\end{array}$ \\
\hline
\end{tabular}

\section{a translated report of a science academic and} Taro's Japanese comments.

This is the first stage of a longer research project involving international collaboration and communication to develop much-needed metrics for informed, meaningful and effective educational practices within virtual worlds. Designing worthwhile tasks that engage students and support learning through inductive and deductive reasoning is challenging enough. When immersed in virtual worlds good task design is essential if students are to meet the intended aim. Tasks are primarily constructed to facilitate a challenging and meaningful process which draws upon students' prior knowledge and transference to new contexts with the intention that these will ultimately lead to achievable outcomes. The iterative task design and implementation employed here draws upon the work of Vygotsky (1986) and Kolb (1984). The results reveal that successful tasks must encourage students to communicate using prominent tools of the environment that are there to use.
The development of these metrics will therefore enable the identification and quantification of learning activities, educational outcomes and pedagogical practice which replicates but does not develop existing practice even when this may initially be obscured within a visually rich and unfamiliar interactive virtual environment. Being able to make these distinctions clearly will be important in using these metrics to design tasks within immersive virtual spaces which do create effective new relationships between learner and teacher to facilitate second order change (Cuban, 1992).

The next phase of the research will involve tasks with more challenging circuits. Task effectiveness and interaction effect will be measured along with coded communicative functions. A framework of informed task design for conducting science-based tasks in virtual worlds will be developed that, in addition to quantitative metrics, will involve students' perceptions of interactions, teamwork, use of prior knowledge, information seeking behavior and problem solving skills. The framework will be linked to learning outcomes and academic competencies 
as described in Martin and Vallance (2008). In addition, a technical challenge will be to develop a software translator that will transfer the information in the NXT block images in the Second Life learning space to NXT program commands for the Mindstorms software so that a direct transference of the program code can be undertaken when the associated icons are invoked.

\section{CONCLUSION}

Currently, measurements used to assess the pedagogical effectiveness and associated knowledge uptake of a given science skills curriculumis measured using standardized achievement tests. Such tests commonly measure changes in acquired basic knowledge but are often incapable of measuring critical thinking ability, task effectiveness, and the contribution of collaborative interactions when engaged in tasks. This research is investigating metrics that can be applied to general and focused science, technology, and engineering learning environments. Controlled experiments with a purposive select group of participants can help establish a framework for effective and successful implementation of a science-based task within virtual collaborative environments. This research limits the virtual word context to the familiar Second Life space. It is anticipated that other virtual worlds will become available to educators in the near future and that our resultant framework and protocols for effective collaborative tasks will still apply. The research is not simply an intellectual pursuit within a novel educational technology environment, but rather an attempt to further the effective and informed use of ICT and the necessary considerations of task design processes and outcomes, teaching pedagogies, and measurements of actual learning. During and after this research period the analysis will be used to implement international collaborative tasks with a more generalized audience of science students. It is anticipated that collaboration with and in virtual immersive interactive environments will become more prominent in mainstream Higher Education within the next five years, and this research aims to provide educators with a framework upon which to construct their curricula, design effective tasks, and assess learning outcomes within such environments.

\section{ACKNOWLEDGMENT}

The research is supported by the UK Prime Minister's Initiative (PMI2) and the Japan Advanced Institute of Science and Technology (JAIST). Many thanks to Taku Suto, Tatsuya Nishi, Hiroshi Numata and Dr. Hartono Pitoyo of Future University Hakodate, Japan, and to ISTE for leasing their SL land.

\section{REFERENCES}

Barker, S. B., \&Ansorge, J. (2007). Robotics as means to increase achievement scores in an informallearning environment. Journal of Research on Technology in Education, 39(3), 229-243.

Brown, A. L. (1992). Design experiments: theoretical and methodological challenges in creating complex interventions in classroom settings. Journal of the Learning Sciences, 2(2), 141-178. doi:10.1207/ s15327809j1s0202_2

Candlin, C. (1987). Toward task-based learning. In C. Candlin \& D. Murphy (Eds.), Language Learning Tasks (pp. 5-22). Englewood Cliffs, N.J: Prentice Hall.

Cuban, L. (1992). Curriculum stability and change. In P.W. Jackson (Ed.), Handbook of research on curriculum (pp. 216-247). New York: Macmillan.

de Freitas, S. (2008). Serious virtual worlds: $A$ scoping study. JISC publications. Retrieved March 14, 2009, from http://www.jisc.ac.uk/publications/ publications/seriousvirtualworldsreport.aspx

de Freitas, S., \& Griffiths, M. (2008). The convergence of gaming practices with other media forms: what potential for learning? Areview of the literature. Learning, media and technology, 33(1), 11-20.

Groff,L., \& Smoker, P. (1997). Introduction to futures studies. Retrieved October 1,2007, from http://www. csudh.edu/global_options/IntroFS.HTML 
Honebein, P. C. (1996). Seven goals for the design of constructivist learning environments. In B. Wilson (Ed.), Constructivist learning environments: Case studies in instructional design. (pp. 3-8). Englewood Cliffs, NJ: Educational Technology Publications.

Iversen, J. S. (n.d). Futures thinking methodologies - Options relevant for "schooling for tomorrow". Retrieved March 14, 2009, from http://www.oecd. org/dataoecd/41/57/35393902.pdf

Jonassen, D. H., \& Land, S. M. (2000). Theoretical foundations oflearning environments. Mahwah, N.J: Lawrence Erlbaum Associates.

Kolb, D. A. (1984). Experiential learning: Experience as the source of learning and development. Englewood Cliffs, N.J: Prentice-Hall.

Martin, S., \& Vallance, M. (2008). The impact of synchronous inter-networked teacher training in information and communication technology integration. Computers \& Education, 51, 34-53. doi:10.1016/j.compedu.2007.04.001

Niemitz, M., Slough, S., Peart, L., Klaus, A. D., Leckie, R. M., \& St. John, K. (2008). Interactive virtual expeditions as a learning tool: The school of rock expedition case study. Journal of multimedia and hypermedia, 17(4), 561-580.

Olsen, D. R., \& Goodrich, M. A. (2003). Metrics for evaluating human-robot interactions. Retrieved March 14, 2009, from http://icie.cs.byu.edu/Papers/ RAD.pdf
Skehan, P. (1998). A cognitive approach to language learning. UK: Oxford University Press.

Taylor, T.L. (2006). Play between worlds: Exploring online game culture. MIT Press: Cambridge, MA. In Coming of Age in Second Life.

Thornburg, D. (2002). The new basics: Education and the future of work in the telematic age. Virginia: ASCD.

Vallance, M. (2007). An information and communications technology (ICT)-enabled method for collecting and collating information about pre-service teachers' pedagogical beliefs regarding the integration of ICT. ALT-J, 15(1), 51-65. doi:10.1080/09687760601129851

Vallance, M., \& Wiz, C. (2007, March). Virtual collaborative spaces. Keynote paper and Podcast presented at North Zone Online ICT Symposium, Singapore. Retrieved March 14, 2009, from http:// www.mshs.moe.edu.sg/symposium2007/keynote. $\mathrm{htm}$

Vygotsky, L. (1986). Thought and language. Cambridge, MA: MIT Press.

Warschauer, M. (1999). Electronic literacies: Language, culture, and power in online education. Mahwah, N.J: Lawrence Erlbaum Associates.

Michael Vallance is a professor at Future University, Japan. He has a doctorate in education from Durham University and a master's degree in computer assisted learning from Stirling University, UK. He is the co-author of Using IT in the Language Classroom and is widely published in educational technology journals. He is involved in a number of ICT research projects such as Task Design for Web 2.0, Podmaps for iPods, and Virtual Collaborative Spaces. His current funding is from the Prime Minister's Initiative (PMI2). His Second Life avatar is Dafydd Beresford.

Stewart Martin is a former secondary school headmaster whose academic and research interests have developed from over thirty years experience in mainstream education. He has acted as an educational consultant to organizations in both the public and private sectors in the UK, the Netherlands and Canada and was for some years a company CEO. He writes and researches in the fields of education, digital technology, citizenship, leadership and educational achievement and has published software and books to support independent learning. His research has been funded by the European Commission (Comenius programme); the Teacher Development Agency; 
the Higher Education Funding Council (HEFCE); and the Prime Minister's Initiative (PMI2) stream from the British Council.

Charles Wiz is a lecturer in the English education department at Yokohama National University, Japan. He has a BA in English literature and an MEd in applied linguistics. His research interests include exploring virtual realities as learning environments, the vocabulary of the Internet and $M M O R P G s$, and second language vocabulary acquisition.

Paul van Schaik is a professor of psychology at the University of Teesside and a National Teaching Fellow, with a special interest in Human-Computer Interaction (HCI). His research focuses on interaction experience ('user experience') and information architecture as well as technology acceptance, web-site usability, electronic performance support and decision-making. His work has been published in leading HCI journals. 